

\title{
To Ensure the Learning of Every Child with a Disability
}

\author{
Richard W. Mainzer, Donald Deshler, Mary Ruth Coleman, \\ Elizabeth Kozleski, and Matty Rodriguez-Walling
}

Today, students with disabilities are identified earlier, attend school, graduate and go on to post-secondary education and jobs in larger numbers, and learn in more inclusive settings than ever in history (American Youth Policy Forum \& Center for Education Policy, 2001). Special education outcomes have never been more positive. Too many students with disabilities, however, still do not graduate from high school, too many are excluded from challenging learning outcomes, too many do not successfully make the transition to independence, and too many end up living lonely, unproductive lives. These quality-of-life indices are inextricably linked to the quality of education that people with disabilities experience. Even though access to a free and appropriate education has been achieved, the educational quality of that experience remains problematic.

The progress that special education has made in its three brief decades of existence is remarkable. Nevertheless, in the same spirit of social justice and advocacy in which special education was born and nurtured, special educators continue to advocate for improvements in the education of students with exceptionalities (Kode, 2002). Today, rather than advocating for inclusion in public education, special educators are working within the general education community to gain genuine access for students with disabilities to the challenging educational results that most individuals in our society take for granted. The push for research-based practice and results-driven accountability is being compromised by a crisis within the special education profession: Special educators labor under work conditions that contribute to attrition rates in special education that are twice as high as those of general educators (NCES, 2000).

Recognizing this burgeoning problem, the Council for Exceptional Children (CEC) established a CEC Presidential Commission on the Conditions of Teaching in Special Education. The Commission (Kozleski, Mainzer, Deshler, Coleman, \& Rodriquez-Walling, 2000) identified three outcomes fundamental to ensuring high and challenging learning results for every exceptional learner:

1. Every student with an exceptionality receives individualized services and supports of caring and competent professional educators.

2. Every special and general educator has the teaching and learning conditions to practice effectively.

Richard W. Mainzer is with the Council for Exceptional Children, Donald Deshler is with the University of Kansas, Mary Ruth Coleman is with the University of North Carolina, Elizabeth Kozleski is at the University of Colorado-Denver, and Matty Rodriguez-Walling is a teacher in the Miami-Dade County Public Schools. 
3. Every instructional leader establishes strong expectations for the use of effective and research-validated instructional practices.

Three years have passed since CEC published Bright Futures for Exceptional Learners (Kozleski et al., 2000). In this article, we review progress on the three outcomes and update the recommendations made in that report.

\section{CARING AND COMPETENT PROFESSIONAL EDUCATORS}

In describing the importance of systematic preparation programs, Darling-Hammond (1997) concluded: "Teacher preparation . . . is by far the strongest correlate of student achievement in reading and mathematics." There is consensus that a quality teacher is the single most important factor in students' learning. In The No Child Left Behind Act (NCLB, 2002), both houses of Congress and the Administration committed the nation to ensuring that every student with disadvantages has a "highly qualified" teacher. Well prepared, beginning teachers have mastered the essential

\section{Focuson
Exceptional
children}

ISSN 0015-511X FOCUS ON EXCEPTIONAL CHILDREN (USPS 203-360) is published monthly except June, July, and August as a service to teachers, special educators, curriculum specialists, administrators, and those concerned with the special education of exceptional children. This publication is annotated and indexed by the ERIC Clearinghouse on Handicapped and Gifted children for publication in the monthly Current Index to Journals in Education (CIJE) and the quarterly index, Exceptional Children Education Resources (ECER). The full text of Focus on Exceptional Children is also available in the electronic versions of the Education Index. It is also available in microfilm from Xerox University Microfilms, Ann Arbor, MI. Subscription rates: Individual, \$36 per year; institutions, $\$ 48$ per year. Copyright (C) 2003, Love Publishing Company. All rights reserved. Reproduction in whole or part without written permission is prohibited. Printed in the United States of America. Periodical postage is paid at Denver, Colorado. POSTMASTER: Send address changes to:

Love Publishing Company

Executive and Editorial Office

P.O. Box 22353

Denver, Colorado 80222

Telephone (303) 221-7333

Karen Harris

University of Maryland

James Shriner University of Illinois
Erica J. Lawrence Editor
Thomas Skrtic

University of Kansas knowledge and skills nationally validated by practicing professionals and aligned with state licensing requirements, including mastery of subject matter.

Knowing content is critical, as the choice of pedagogy is informed by the nature of the information to be taught. Because students with disabilities rely on special educators' intervention across academic content areas, special educators must have a working knowledge of a wide array of subject-matter content across the general curriculum. When deep understanding of a subject matter is critical to designing new curriculum or helping students acquire new skills, special educators routinely collaborate with appropriate subject-matter specialists and general educators to adapt the content to the individualized needs of their students. For some individuals with disabilities, special educators provide rich individualized curricula to foster successful and fulfilling growth and independence in students. In a very central way, pedagogy is at the heart of practice in special education. Special educators are responsible for effectively altering instructional variables to optimize the learning of students with exceptionalities in whatever curriculum is most appropriate.

The Bright Futures for Exceptional Learners was designed to stem the tide of unqualified and underqualified instructors teaching students with exceptionalities. Yet, 3 years after its publication, even more unqualified individuals are teaching the students who need the most qualified and skilled special educators. Today, approximately 40,000 individuals teach approximately three quarters of a million students without having met even minimum state licensing requirements (USDOE, 2001). Approximately one in every 10 individuals practicing as special education teachers is not minimally qualified (Carlson \& Billingsley, 2001). Of all new special education teachers, $32 \%$ are not fully certified (Boe, Cook, Bobbitt, \& Terhanian, 1998). The strongest correlate of students' performance on national assessments is the percentage of fully qualified teachers (Darling-Hammond, 1998). Achieving educational parity for students with exceptionalities seems even more distant today.

If special education is to achieve high-quality results for all students in special education, the nation must recruit and prepare greater numbers of motivated and committed special education teacher candidates. Further, the nation's teaching force is overwhelmingly female (88\%) and caucasian (92\%) while the ethnic and linguistic diversity of our communities grows (NCES, 2000). Improved life chances of students of color demand that the field recruit and retain qualified teachers of color to our classrooms in general and special education. Given that the attrition rate in special education is twice that of general education, we must implement policies that effectively encourage the good teachers we have to make special education teaching a career. Finally, most states need 
to increase the capacity of their preparation programs. Whether this is accomplished through well designed and documented alternative preparation programs or through statewide coordinated systems of higher education, the state must accept its dual responsibilities of program accreditation and individual licensure as the best guarantee to the community that its teachers are prepared for professional practice.

The unprecedented demand for special educators can distract us from issues of teacher quality with shortsighted solutions focusing on quantity over quality. Moreover, the Study of Personnel Needs in Special Education (SPENSE, 2000a) documented that the use of unqualified individuals is felt most keenly in districts that have the highest levels of poverty. Teachers earn less than any other profession with a similar level of college preparation (National Center for Educational Statistics, 1992). Compensation does make a difference. Careers in teaching must be competitive with other equally preparation-intensive professional fields. In addition, respect given to them must parallel that for other professions, and career ladders that make continuing classroom practice a respected and viable career option must be implemented.

It is not encouraging when the U. S. Department of Education regulations regarding NCLB permit individuals who have never taught a class to be called "highly qualified" by simply being enrolled in a preparation program (NCLB Improving Teacher Quality State Grants, 2002). Some states are implementing "quick fix" programs to increase the number of teachers they produce. These quick-fix alternative preparation programs lower quality standards by assuming that special educators can be prepared for professional teaching responsibilities in a matter of weeks. No Child Left Behind has laid the groundwork to eliminate the use of unqualified individuals teaching disadvantaged students. The upcoming reauthorization of IDEA must require states to ensure that all special education teachers are fully prepared and qualified. There are no short-cuts to attracting, preparing, and retaining a sufficient cohort of caring and competent teachers. "Quick fixes" only exacerbate problems of both quantity and quality, and some data indicate that individuals prepared in these programs leave the profession at higher rates (Barry, 2003). Setting and holding rigorous expectations for quality is the only way to genuinely encourage individuals to select special education teaching as an initial or second career.

In other professions, practicing without a license is illegal. Teachers should be held to the same standard. Unprepared, and therefore unqualified, individuals should not be allowed to assume the mantle of professional teachers. Perhaps the most insidious deceit is that, in allowing unqualified people to practice as special educators, parents and community members are led to believe that children are receiving the educational supports and services they need to succeed. The special education profession must demand that all teachers demonstrate their competence to teach through robust teacher-preparation and rigorous licensure standards.

States also must assure that programs that prepare special educators meet rigorous national accreditation standards that require the programs to demonstrate what their teachers in training learn, not simply what they were taught or how many courses they took. In combination, program accreditation and individual licensing provide parents and the community the best assurance that the teacher possesses the nationally recognized knowledge and skill to practice safely and effectively.

\section{Comprehensive Coordinated Workforce Planning}

The severe and chronic shortage of special education teachers is well documented (ERIC, 2001, Carlson \& Billingsley, 2001; USDOE, 2001); $98 \%$ of the nation's school districts are reporting shortages (AAEE, 1999). Many state agencies do not know how many new special educators are prepared within the state each year, or how many positions will become vacant each year. The answers to a myriad of important questions depend on the use of complex, comprehensive workforce planning models. If states are to assure a sufficient supply of well qualified educators, the stakeholder agencies, including school districts and preparation programs within states, must actively develop and implement coordinated comprehensive workforce-planning models in which the needs of all parties are considered.

Because states retain primary responsibility for education, the repair and transformation of the serious shortages of qualified teachers requires swift and effective policy implementation in each state. States must work with their local school systems to develop recruitment packages that will attract academically competent college students to careers in teaching. These packages must develop competitive salary scales that encourage well educated college graduates to choose teaching as well as law, medicine, and architecture as a respected and well compensated career. This means that states must develop and implement coordinated recruiting campaigns, unified job information banks, and streamlined application processes. Every state should establish a workforce-planning group made up of the stakeholders with the staff and resources to analyze, develop strategies, and disseminate their findings widely to the public regarding concerns such as:

- The extent to which the state infrastructure can provide the teachers and teacher educators needed over a forecast period

- Effective and ineffective strategies to retain teachers 
- Effective and ineffective strategies to recruit a sufficient cohort of diverse teachers at both career entry, and mid-career points

- The extent to which special resources and strategies are needed to address specific situations (e.g., urban districts, preparation of teachers for low-incidence populations)

- Effective and ineffective models for career ladders in classroom teaching and the extent to which they are implemented across the state

- Effective and ineffective models for attracting paraeducators into special education and the extent to which they are implemented across the state

- Effective and ineffective models for induction and mentoring and the extent to which they are implemented across the state

- Effective and ineffective models for licensing entry level and advanced teachers and the extent to which they are implemented across the state.

If states are to begin to address the shortage of special education teachers, they must systematically collect the complex information to provide strategies to these and other complex questions. In addition, states must do all of this publicly, in ways that allow for separation of the data so it is usable by local school districts and for subpopulations, as well as statewide. Every school district should be required to collect information on the conditions in which special educators practice, including role ambiguity, paperwork, caseloads and class sizes, teacher credentials, administrative training, professional development, salaries and their competitiveness compared to other professionals. They must also be expected to use this information as the basis for strategic recommendations to improve the conditions.

\section{Professional Development}

The survey conducted for Bright Futures for Exceptional Learners (Kozleski, Mainzer, Deshler, Coleman, \& RodriguezWalling, 2000) found that expectations for meeting the needs of students with exceptionalities have changed dramatically over the years. These changes include greater responsibilities for classroom teachers, the need for collaboration between general and special educators, and the increased emphasis on high standards of learning for all students. The general education teachers expressed feelings that they had not been adequately prepared to meet exceptional students' needs in their preservice programs and concern that they were not being given enough professional development support to compensate for this.

Special educators' concerns were centered on their lack of preparation for their roles in collaboration and contentrelated teaching. Overall, the administrators said they were very satisfied that their professional development was adequate and in place, whereas the teachers said that they do not have the knowledge and skills they need and that they were not being given professional development to acquire them.

\section{TEACHING AND LEARNING CONDITIONS TO PRACTICE EFFECTIVELY}

If all children with exceptionalities are to achieve high and challenging learning outcomes, special educators must have working conditions that allow the use of strong and effective instructional interventions. When job responsibilities are ambiguously defined and the work conditions offer little support, it is not surprising that those who hold these jobs have high levels of stress and leave in large numbers, and that few new individuals are attracted to careers in these jobs (SPENSE, 2001a; Mandlawitz, 2003).

\section{Paperwork}

Over the past two decades, the paperwork requirements of IDEA have increased to a point at which paperwork significantly reduces the amount of time that special educators can spend on instructional time. In a national study of special education, SPENSE (2001b) corroborated the Bright Futures for Exceptional Learners finding that special education teachers report spending twice as much time as general educators on what they perceive as compliance-focused paperwork that interferes with instructional time and positive communication with parents and colleagues. Special educators also reported a lack of clerical support for routine paperwork tasks and inadequate access to technology to facilitate paperwork tasks.

Yet, school districts continue to spend millions of dollars per year on triplicate forms and expect special educators to complete lengthy and complex forms. Teachers today are expected to operate in an information-based, technologydriven environment with tools from the industrial age. Virtually all professional fields except special education have specially designed software to manage and organize their tasks and records. In a time when even the UPS delivery driver uses a computer to plan deliveries and the recipient can check the delivery status virtually from anywhere at any time, it is time that special educators have appropriate technology to ease the paperwork burden.

In many school districts individuals largely untrained in information management systems developed the forms for documenting special education decisions. The result is the fragmented paperwork that we have today. These poorly designed forms accumulate into inadequately conceived and fragmented systems. It is time that states take a leadership role in developing well conceived, coordinated, and technologically based documentary systems with their school districts. 
It is also time for policymakers to seriously consider how to reduce the litigiously oriented paperwork burden that has been placed on the shoulders of special educators. As Bill East, the director of the National Association for State Directors of Special Education, put it, "It is time for parents and educators to take back control of education from the attorneys (Tschantz \& Markowitz, 2002, p. 25)."

With well designed technological solutions, timely reports and forecasts can be generated with the touch of a key. IEPs that address the unique needs of each child can be developed efficiently. Special education records can be confidentially transmitted instantaneously. With this type of software, teachers can lift their eyes from the pile of triplicate forms and make plans to address genuine educational needs with their colleagues, parents, and students. Moreover, there is simply no reason to use the most important and expensive resource, the teacher, to manage routine recordkeeping tasks. Every special education program should have the support of a clerical assistant specifically trained in special education records.

\section{Role Definition}

Special educators assume a wide array of responsibilities depending on the specific context of the school and the needs of the individuals. But this cannot overshadow the importance of role clarity. The relationship of role ambiguity and job stress is strong and convincing (Billingsley, 1991; Singh \& Billingsley, 1996). Moreover, Gersten, Keating, and Harniss (2001) found that poorly designed jobs affect teachers in negative ways, leading to withdrawal in the job to eventually leaving the position or the field.

School districts must clearly design job responsibilities of each of the special education positions within the agency and communicate them to parents, general educators, and the community. These roles may include responsibilities, such as direct, intensive, explicit instruction of students, ongoing collaboration and planning with professional colleagues, supervision of clerical and other assistants, administration and analysis of various special assessments, and communications and collaboration with parents and other individuals involved in the student's instruction.

The difference between how administrators and teachers perceive the need for and availability of communication and time for collaboration is striking (Kozleski et al., 2000). General and special education teachers alike indicated that they must have more time for collaboration and more ways to establish clear communication with each other if they are going to be able to meet the needs of their students with exceptionalities. They believe that, given the changing expectations and roles, the need for intense and ongoing collaboration is greater now than ever. Yet, the administrators indicated that they are satisfied that teachers have what they need to appropriately communicate and collaborate to meet the needs of their students with exceptionalities.

\section{Caseloads}

Closely related to role definition and paperwork are questions about how many students with disabilities a special educator can reasonably be expected to serve and implement the individualized instruction and close collaboration that is essential to students with disabilities. In a study of burnout and job dissatisfaction among nurses, Aiken, Clarke, Sloane, Sochalski, and Silber (2002) found that in hospitals with high nurse-to-patient ratios, surgical patients experienced higher risk-adjusted 30-day mortality and failure-to-rescue rates, along with increased rates of burnout and job dissatisfaction among the nurses. Clearly, class size and caseloads may have important implications for the achievement of students with disabilities and implications for reducing job stress and high attrition among special educators.

The relation between class size and achievement in general education classrooms has been studied and discussed extensively over the past several decades (Goldstein \& Blatchford, 1998, Wested, 1999, Odden, 1990, Glass \& Smith 1979, Slavin, 1986). More than half of the states currently have initiatives to reduce class size (Russ, Chiang, Rylance, \& Bongers, 2001; Wexler et al., 2001). Yet, research on caseload, class size, and achievement in special education is relatively rare. In a review of the research, Russ et al. (2001) found that larger caseloads negatively impact students' math and reading achievement, individualization is more likely to occur in smaller groups, student engagement and achievement increase with smaller group sizes, and high teacher attrition and large caseloads seem to be related.

Unfortunately, caseloads and class sizes in special education remain highly inconsistent from state to state and even district-to-district (Ahearn, 1995). One troubling trend is that states seem to be abandoning statewide guidelines by allowing school districts to set whatever caseloads and class sizes they choose. During the research for Bright Futures for Exceptional Learners, special educators in forums around the United States reminded the CEC Presidential Commission that it is more complex than just the numbers of students in a class or caseload. Factors such as the range of grade levels and subject areas for which they are responsible, and the variations in their students' exceptionalities, also must be considered.

In addition, the time it takes special educators to provide consultation must be factored. Beginning this year, CEC will develop national benchmarks for caseloads and class sizes, collect relevant state law or guidelines, actual caseloads, and class sizes by state for use by policymakers. 


\section{Administrative and Collegial Support}

In the survey of general and special administrators and teachers for Bright Futures for Exceptional Learners (Kozleski, Mainzer, Deshler, Coleman, \& Rodriguez-Walling, 2000), administrators and teachers reported very different perceptions of the conditions that teachers faced in the classroom. Teachers reported more difficulties with the conditions they face than the administrators perceived. Another concern expressed by special education teachers in the same survey was a feeling of isolation from their school and special education colleagues. Special educators commented on the general education teachers' frustration in teaching students with exceptional learning needs. The special educators went on to say that this frustration was projected onto the special education teachers. As a result, special educators who work with students with the most intense needs are left feeling as if they receive the least amount of support.

One of the key elements of job satisfaction and retention is a sense that what we do is understood and appreciated by those for whom we work. In the case of teachers, this is the perception that administrators and colleagues understand and support the effort that goes into teaching. Gersten et al. (2001) found that building-level support from school administrators and other colleagues has a strong and direct effect on all critical aspects of teachers' working conditions. When administrative and collegial support is in place, teachers tend to feel positive about their work. When this understanding and support is perceived to be lacking, however, there is a profoundly negative impact (Gersten et al., 2001). The striking differences in perception between the administrators and teachers participating in the survey about the conditions of teaching children with exceptionalities is troubling and corroborates teachers' anecdotal reports that administrators do not understand what teachers are faced with in today's teaching world. Given these differences, it may not be surprising that the one area surveyed in which administrators were more positive than teachers was in "satisfaction with their work."

School principals and assistant principals are assuming more responsibility for the special education and related personnel and services. As the instructional leader of the school, the school administrator must understand and be able to clearly communicate, to parents, the community, and other colleagues, the scope and purpose of special education services. It is no longer sufficient to prepare administrators with broad platitudes such as "All means all" or "Leave no child behind." To use a metaphor, training with broad platitudes is like getting to know the United States by taking a supersonic jet from coast to coast. A more apt metaphor is the need for a bus ride from coast to coast. If special education services are to be genuinely included in the school culture, prospective school administrators must be explicitly and deeply prepared in the supervision, development, and evaluation of special education and related services within the schools and in how to effectively address their responsibilities for the individuals with exceptionalities in their schools.

In addition, like other preparation programs, programs preparing school administrators should be accountable to demonstrate that their graduates have mastered the knowledge and skills to explicitly develop, supervise, and improve school-based special education programs and services. Programs that prepare school administrators must evaluate the depth and breadth of special education knowledge and skill they require. Moreover, school districts must offer targeted professional development opportunities for their existing school administrators.

\section{STRONG EXPECTATIONS FOR EFFECTIVE VALIDATED INSTRUCTIONAL PRACTICES}

One of the major findings of the Bright Futures for Exceptional Learners study was the often insufficient focus on student outcomes. This finding is especially troubling in light of some highly significant policy shifts and emphases in recent years and months. First, the reauthorization of IDEA in 1997 marked a major shift in the law's intent. For the first time, schools were explicitly directed to measure the outcomes achieved by students and to include students with disabilities in accountability systems. Prior to 1997 , IDEA had focused largely on the processes and procedures to ensure that all students with disabilities would receive a free and appropriate education. Second, with the NCLB, passed in 2001 (NCLB, 2002) and the publication of A New Era: Revitalizing Special Education for Children and Their Families (2002), the emphasis on achieving positive outcomes for students outlined in IDEA 1997 was strongly underscored; however, the bar was set even higher for educators by NCLB in calling for students to be taught with "scientifically based instructional practices."

Indeed, one of the cornerstones of the NCLB (2002) that was passed is its call for educational practices to be grounded in "scientifically based research." In that particular bill, the phrase "scientifically based research" appears 111 times. A belief shared by the U.S. Congress and the Administration alike is that improved outcomes for students must be linked to educational practices solidly grounded in research. Effective and validated practices based on scientifically based research are expected to be a central feature in the reauthorization of IDEA in the coming months.

Given the importance of ensuring that any investments on behalf of individuals with disabilities yield optimal outcomes, it is encouraging to have legislative initiatives that deal with individuals with disabilities tied so closely to 
instructional practices that have been shown to make a difference in the performance of individuals. As encouraging as it is to have legislation espousing and even requiring the use of scientifically based practices, there is no guarantee that results in our nation's classrooms will change unless we seriously confront the broad array of issues involved in effectively translating promising research findings into practice.

For years, educational practice has been plagued by the infamous research-practice gap (e.g., Carnine, 1997; Elmore, 1996; Gersten, Vaughn, Deshler, \& Schiller, 1997; Greenwood \& Abbott, 2001; Kauffman, 1996; Kennedy, 1997; Robinson, 1998). Too often, research in special education has been limited to small-scale fragmented research initiatives. Simply because a line of research has demonstrated promise in small-scale studies is no guarantee that the innovation will stand up in large-scale initiatives or whether it can be successfully integrated into the array of responsibilities expected of teachers. Although encouraging results continue to emerge in small-scale research studies, they rarely are brought to scale and sustained over a sufficiently extended period in a broad array of settings and under differing conditions. Only when a so-called scientifically based practice has been shown to get results in a scaled-up and sustained fashion can we say that it is scientifically based. If the practice ends up sitting on the shelf in classrooms because it is too cumbersome or burdensome, we must question the overall value of its contribution and the standards that lead to it being labeled as "scientifically based." Unless an innovation has been proven effective and usable in frontline settings, researchers cannot legitimately claim that an innovation is scientifically based. In short, if questions of external validity have not been answered satisfactorily in a broad array of contexts, the claim of "scientifically based" is premature.

Is it sufficient for educators and administrators to focus solely on the use of scientifically based instructional practices to improve student outcomes? If it isn't sufficient, what else must be in place to make a significant difference? During the past 25 years five important factors have emerged in the professional literature that, when applied collectively, have a high probability of improving student outcomes. These five factors might be conceptualized in terms of a "student success formula." That is, the probability of student success is significantly increased to the extent that each factor included in the student success formula is present. These factors, illustrated in Figure 1, are: validated interventions, fidelity of implementation, coordinated implementation, strong administrative leadership, and quality professional development.

Validated Interventions<smiles>[TeH]</smiles>

Fidelity of Implementation<smiles>[TeH]</smiles>

Coordinated Implementation<smiles>[TeH]</smiles>

Strong Administrative Leadership $+$

Quality Professional Development

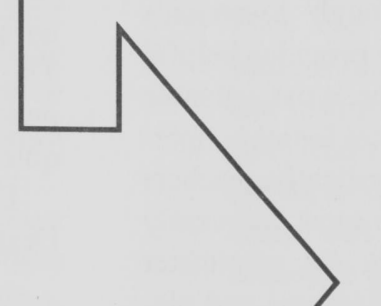

Student Success 


\section{Validated Interventions}

Consistent with the expectations of NCLB 2001 and the report of the Presidential Commission on Excellence in Special Education (2002), validated interventions must be viewed as the core element in bringing about significant student gains. In the absence of effective and validated instructional practices, the likelihood of gains is greatly diminished. The field of special education is markedly different today than it was when PL 94-142 was originally passed. Several instructional materials and practices have been validated. For example, through the support of the U.S. Department of Education, Office of Special Education Programs and the National Center for Learning Disabilities, several meta-analyses have synthesized the research in the following topics:

- Higher-order processing and problem solving (Swanson, 1999)

- Reading comprehension (Gersten, Williams, Fuchs, \& Baker, 1998)

- Written expression (Gersten \& Baker, in press)

- Grouping practices (Elbaum, Vaughn, Hughes, \& Moody, 1999).

A review of these meta-analyses underscores the fact that special educators can call upon a significant array of validated instructional practices when designing programs for students with disabilities. Swanson (1999) found that the two most effective instructional programs for students with specific learning disabilities (LD) were direct instruction and learning strategy instruction. Although Swanson's meta-analysis of the intervention literature provides helpful direction to special educators, perhaps the most valuable part of this analysis is the types that Swanson found to operationally define each of these models. Specifically, teachers who used a direct instruction model were most frequently found to (a) break tasks into small steps, (b) administer probes, (c) supply feedback, (d) provide diagrams and pictures to enhance comprehension, and (e) provide ample independent practice. In contrast, teachers who implemented a learning strategies model were most frequently found to (a) provide elaborate explanations, (b) model learning processes, (c) provide prompts to use strategies, (d) engage in teacher-student dialogues, and (e) ask processtype questions. In short, the largest effect sizes in more than 270 intervention studies were produced when teachers incorporated instruction that was in alignment with these features.

In an article designed to summarize the prevailing messages in each of the meta-analyses cited above, Vaughn, Gersten, and Chard (2000) were able to draw several conclusions about existing validated instructional practice for students with disabilities. They found that the instructional practices that are visible and explicit, interactive between students and teacher and between students and students, controlled for task difficulty, and include strategies to guide student learning result in the greatest student achievement. The most pressing challenge, however, is to bring our level of implementation into alignment with what we know makes a difference for students with disabilities.

\section{Fidelity of Implementation}

The overall effectiveness of an intervention is tied closely to two factors: (a) how the intervention is designed and (b) how the intervention is taught. Fidelity of implementation is tied directly to the second factor. As defined in Webster's, fidelity means "strictness and thoroughness of performance, with exactness, with accuracy." Given the problems that many students with disabilities exhibit in information processing, teachers must carefully adhere to well established principles of learning and pedagogy, as well as strictly follow the instructional details outlined in intervention manuals or protocols.

When an intervention procedure is validated, it is taught according to a specified set of instructional guidelines. To reasonably expect similar results with a given intervention in "scaled-up" practice, the guidelines and principles of the intervention must be absolutely clear. An example of an instructional sequence that has been found to produce large effective sizes when teaching different learning strategies to students with disabilities to help them perform well in school has been validated by the University of Kansas Center for Research on Learning (CRL) (Deshler et al., 2001). This instructional sequence has been found to be sufficiently powerful to enable students with LD to learn strategies quickly and efficiently.

Eight stages comprise the instructional sequence (Ellis, Deshler, Lenz, Schumaker, \& Clark, 1991):

1. Pretest and make acquisition commitments

2. Describe

3. Model

4. Verbal practice

5. Controlled practice and feedback

6. Advanced practice and feedback

7. Posttest and make generalization commitments

8. Generalization

Instruction within these eight stages is provided in the context of a learning apprenticeship (Hock, Schumaker, \& Deshler, 1995) in which the teacher takes an active role in describing and modeling for students alternative ways to approach tasks in more potentially efficient and effective ways. As students begin to understand what being a strategic 
learner is all about, some of the scaffolding is removed and instruction shifts from an emphasis on teacher-mediation to an emphasis on student-mediation in the later stages of instruction (e.g., Deshler et al., 2001; Hock, Deshler, \& Schumaker, 1993).

Validated interventions are generally successful because they are based on well established principles of learning and instruction. When implementation procedures for validated interventions are varied, they no longer follow validated procedure and the results on student performance are simply unknown. In short, implementation with fidelity is imperative to optimize student outcomes.

\section{Coordinated Implementation}

For students with disabilities to reduce the sizable deficits that characterize many of their profiles as learners, their instruction must be well coordinated in terms of the short- and long-term goals specified in their IEPs, as well as how the instruction is implemented and reinforced across teachers and settings alike. If the instruction is not clearly focused, carefully orchestrated, and precisely planned, the gains may be significantly reduced. First, an instructional plan must be conceptualized to systematically address the deficit areas targeted by the IEP. To do so, one skill or strategy has to be built upon another so students' overall competence in a deficit area is dramatically improved. As an example, if a student has significant deficits in written expression, the instructional plan specified by the IEP may call for intensive instruction in a validated scope and sequence of instruction in written-expression strategies including sentence writing, paragraph writing, theme writing, and error monitoring (Deshler, Ellis, \& Lenz, 1996). If achieving these instructional goals takes more than one semester or academic year, alignment between instructional activities and IEP goals must be maintained to a high degree.

In addition, students with disabilities must receive instruction that is carefully coordinated across all of their teachers and different educational settings. This can be illustrated by considering a student with disabilities, Jason, who is in an elementary fifth-grade classroom. Jason has one teacher who is responsible for teaching all of his academic subjects and a special education resource services teacher who provides special education supports. Under this scenario, the fifth-grade teacher and special education teacher can readily collaborate and coordinate their instruction for Jason. The targeted skills or strategies that Jason is learning from the special education teacher should be ones that will help him respond successfully to the demands of the general education curriculum. In turn, the general education fifthgrade teacher can prompt and reinforce Jason's use of these targeted skills and strategies in each of the academic subjects and assignments throughout the school day.
When Jason moves from his elementary school to a middle school the following year, however, the challenge of collaboration among Jason's teachers around the coordination of his instruction across settings becomes much more challenging. The first step will be for Jason's fifth-grade teachers to collaboratively communicate with his sixth-grade special and general education teachers. More often than not, this communication link is not done well and the work with Jason in his new school is often unrelated to what occurred during the fifth-grade. Often the special educators, as case managers, have to take on the responsibility of forging strong communication links to ensure that the targeted skills and strategies in a student's IEP are continually stressed and practiced mastery will be a higher probability.

In the case of Jason, if his special education teacher were teaching him a vocabulary strategy to use in his classes, Jason optimally would master the strategy and see its relevance if each of his teachers would incorporate it into his or her classroom and set the expectation for Jason to apply the vocabulary strategy in all of his work in that class. When this type of collaboration and carefully coordinated instruction occurs across teachers and settings, it promotes learning, mastery and overall student success.

\section{Strong Administrative Leadership}

School administrators play a vital role in ensuring that each of the factors in the student success formula (see Figure 1) are in place. They can put the weight of their office behind the implementation of each factor in a variety of ways:

- They can advocate for funding from a variety of sources (e.g., the State, district, grants), set priorities, and restructure their budget allocations.

- They can ensure that research-based interventions are the focus of professional development activities.

- They can structure the professional development sequence to incorporate the four phases above.

- They can actively participate in all professional development activities.

- They can take an active role as instructional leaders by visiting classrooms, taking part in support team meetings, insisting that interventions be implemented, and ensuring that each staff member is accountable for student outcomes.

They also can ensure that the special educators have well defined roles that are clearly supported and communicated to parents and teachers. They can ensure that caseloads and other working conditions are in place so teachers can use validated and effective instruction, Finally, they can develop and implement schedules to optimize the communication and collaboration that is so critical to coordinating instruction. 


\section{Quality Professional Development}

The vital role that quality professional development plays in improving students' outcomes has been repeatedly emphasized in the literature (e.g., Archer, 1999; Olson, 1997; Sanders, 1999). Professional development has to focus on changing instructional practice by ensuring that teachers use effective and validated practices. Further, equal attention must be directed to how professional development experiences should be conceptualized and delivered.

First, the content of staff development should emphasize instructional practices that are effective and validated. When a practice that does not have strong validation is recommended, it must be accompanied by clear and appropriate cautions. A research synthesis by Wang, Haertel, and Walberg (1993) provides direction regarding the kind of information around which professional development should be based. Their meta-analysis found that student learning was most affected when teachers focused instruction on key "proximal" variables such as students' self-regulation of their academic behavior, students' perseverance and enthusiasm for learning, the amount and quality of teacher-student interactions, and teacher modeling of appropriate academic behaviors.

Wang et al. (1993) found that proximal variables are more highly related to positive student outcomes than distal variables (i.e., variables not directly related to the studentteacher interactions, such as moving from a junior high school structure to a middle school structure). To achieve the greatest change in student performance, professional development programs should focus on proximal variablesthose related to the instructional methods used with students with disabilities. The importance of focusing professional development on factors that lead to the largest student outcomes is especially important given Carnine's (1995) finding that the vast majority of interventions and materials that dominate current practice with students with disabilities are not validated.

Once the content of a professional development program has been chosen, the next issue is how to conceptualize and deliver the professional development program. To bridge the gap between research and practice - to make validated interventions available to teachers in a manner that will maximize their use over a sustained period and to impact student behavior in a positive way-professional development programs must be carefully structured. Several studies have identified ways to best provide professional development and enhance implementation rates. Most important, professional development must be viewed as a continuous process involving everyone in the school. Instead of participating in fragmented, one-shot sessions about a variety of topics, teachers have to participate in a planned sequence of learning sessions that they see as relevant to their role in the educational mission.

The professional development sequence must consist of at least four phases (Deshler \& Schumaker, 1996; Ehren, 1999; Schumaker \& Clark, 1990):

1. Initiation (to give basic information to potential implementers to help them determine the extent of appropriateness and alignment between the attributes of an innovation and existing instructional needs).

2. Learning and implementation (to give in-depth explanations, models, and practice and feedback).

3. Follow-up support (to back implementation efforts through coaching, troubleshooting, support-team meetings, and implementation refinement).

4. Maintenance (to establish the innovation within the system as routine).

\section{CONCLUSION}

Although the nation has made substantial progress over the last three decades in improving the education of students with disabilities, there is much left to do. The threefold focus laid out in Bright Futures for Exceptional Learnersthat every child with exceptionalities receive individualized services and supports from competent and caring professionals; that special and general educators teach under conditions that support success; and that instructional leadership establish the expectation that effective and valid practices will be in place - provide the nation with the prerequisites to ensure that all children with exceptionalities achieve high and challenging learning outcomes.

The special education field will continue to lose its workforce without the active engagement of state and local policymakers who collaborate to ensure the following.

1. Robust teacher preparation programs must demonstrate that teacher education graduates develop content-area expertise, make professional judgments among research-validated practices to match student need to the appropriate pedagogy, and use student performance data to continuously refine and improve their teaching practices.

2. Rigorous licensure standards have to be upheld even as states and local education agencies develop and refine alternative routes to licensure.

3. General and special educators alike are expected to modify, adapt, and accommodate their teaching practices to meet the educational needs of students with exceptionalities.

4. States and districts must develop information systems that relieve educators from the burden of excessive paperwork but maintain the original intent of the 
individualized educational program: accountability for results, effective and frequent communication with families, and clear expectations for what is to be learned.

5. States have to support local educational agencies by developing statewide recruitment and retention efforts designed to attract the most highly educated individuals to the teaching profession, emphasizing the importance of providing opportunities for children to learn from an ethnically, culturally, and linguistically diverse teaching force.

The issues and strategies presented here outline a blueprint for success. The responsibility to see that they happen is shared by educators, policymakers, families, and community members who all have a stake in the education of students with disabilities. Education is emancipation and therefore holds the greatest promise for enhancing the quality of life for each student, including those with the greatest need. During the next three decades the field can advance as much or more than it has in the past 30 years. It can be done if we have the collective will to do so.

\section{REFERENCES}

Ahearn, E. (1995). Caseload/class size in special education: A brief analysis of state regulations. Alexandria, VA: National Association of State Directors of Special Education.

Aiken, L., Clarke, S., Sloane, D., Sochalski, J., \& Silber, J. (2002). Hospital nurse staffing and patient mortality, nurse burnout, and job dissatisfaction. Journal of the American Medical Association, 288, 19871993.

American Association for Employment in Education. (1999). Teacher supply and demand in the United States. Evanston, IL: Author.

American Youth Policy Forum \& Center for Education Policy (2001). Twenty-five years of education children with disabilities: The good news and the work ahead. Washington, DC: Author.

Barry, B., (2003). Quality alternatives in teacher preparation: Dodging the "silver bullet" and doing what is right for students. Chapel Hill, NC: Southeast Center for Teaching Quality. Retrieved on February 25, 2003 at http://www.teachingquality.org/resources/articles/silverbullet. $\underline{\mathrm{htm}}$

Billingsley, B. (1993). Teacher retention and attrition in special and general education: A critical review of the literature. Journal of Special Education, 27, 137-174.

Billingsley, B. (1991). Teachers' decisions to transfer from special to general education. Journal of Special Education, 24, 296-511.

Billingsley, B., \& Tomchin, E. (1992). Four beginning LD teachers: What their experiences suggest for trainers and employers. Learning Disabilities Research and Practice, 7, 104-112.

Billingsley, B., Bodkins, D., \& Hendricks, M. B. (1993). Why special educators leave teaching: Implications for administrators. Case in Point, 7 , 23-38.

Boe, E. E., Cook, L. H., Bobbitt, S. A., \& Terhanian, G. (1998). The shortage of fully certified teachers in special and general education. Teacher Education and Special Education, 21, 1-21.
Carlson, E., \& Billingsley, B. (2001). Working conditions in special education: Current research and implications for the field. Paper presented at OSEP Project Directors' Conference, July 2001.

Carnine, D. (1995). The professional context for collaboration and collaborative research. Remedial and Special Education, 16 (6), 368-371.

Carnine, D. (1997). Bridging the research-to-practice gap. Exceptional Children, 63(4), 513-521.

Darling-Hammond, L. (1992). Teaching and knowledge: Policy issues posed by alternative certification for teachers. Peabody Journal of Education, 67, 3, 123-154.

Darling-Hammond, L. (1997). Doing what matters most: Investing in quality teaching. New York: National Commission on Teaching and America's Future.

Darling-Hammond, L. (1998). Teachers and teaching: Testing policy hypotheses from a national commission report. Educational Researcher, $27(1), 5-15$.

Darling-Hammond, L. (2000). "Teacher Quality and Student Achievement." Educational Policy Analysis Archives, 2000.

Deshler, D.D., Ellis, E. S., \& Lenz, B. K. (Eds.) (1996). Teaching Adolescents with Learning Disabilities: Strategies and Methods. Denver: Love Publishing.

Deshler, D. D., \& Schumaker, J. B. (1996). Getting research into the classroom. Their World, 16-18.

Deshler, D.D., Schumaker, J.B., Lenz, B.K., Bulgren, J.A., Hock, M.F., Knight, J., \& Ehren, B.J. (2001). Ensuring content-area learning by secondary students with learning disabilities. Learning Disabilities Research and Practice, 16, 96.

Ehren, B. (1999). Language-sensitive SIM: Part 1. Stratenotes, 7(5), 1-8.

Elbaum, B., Vaughn, S., Hughes, M. T., \& Moody, S. W., (1999). Grouping practices and reading outcomes for students with disabilities. Exceptional Children, 65, 399-415.

Ellis, E.S., Deshler, D.D., Lenz, B.K., Schumaker, J.B., \& Clark, F.L. (1991). An instructional model for teaching learning strategies. Focus on Exceptional Children, 24(1), 1-14.

Elmore, R. F., (1996). Getting to scale with good educational practices. Harvard Educational Review, 66(1), 1-26.

ERIC Clearinghouse on Disabilities and Gifted Education (2001, April). Educating exceptional children: A statistical profile. Arlington, VA: Council for Exceptional Children.

Gersten, R., \& Baker, S. (in press). Teaching expressive writing to students with learning disabilities: A meta-analysis. Elementary School Journal.

Gersten, R., Keating, T., \& Harniss, M. (2001). Working in special education: Factors that enhance special educators' intent to stay. Exceptional Children, 67, 549-567

Gersten, R., Vaughn, S., Deshler, D. D., \& Schiller, E. (1997). What we know about using research findings: Implications for improving special education practice. Journal of Learning Disabilities, 30(5), $466-476$.

Gersten, R., Williams, J., Fuchs, L., \& Baker, S. (1998). Improving reading comprehension for children with learning disabilities (Final Report: Section 1, U.S. Department of Education Contract HS 921700). Washington, DC: U.S. Department of Education.

Glass, G. V., \& Smith, M. L. (1979). Meta-analysis of research on class size and achievement. Educational Evaluation and Policy Analysis, 1, 2-16.

Goldstein, H. \& Blatchford, P. (1998). Class size and educational achievement: A review of the methodology with a particular reference to study design. British Educational Research Journal, 24, 225-239.

Greenwood, C. R., \& Abbot, M. (2001). The research to practice gap in special education. Teacher Education and Special Education, 24(4), 276-289. 
Hock, M. F., Deshler, D. D. \& Schumaker, J. B. (1993). Learning strategy instruction for at-risk and learning-disabled adults: The development of strategic learners through apprenticeship. Preventing School Failure, 38(1), 43-49.

Hock, M.F., Schumaker, J.B., \& Deshler, D.D. (1995). Training strategic tutors to enhance learner independence. Journal of Developmental Education, 19, 18-26.

Improving Teacher Quality State Grants: Title II, Part A Non-Regulatory Draft Guidance, December 2002 (Question C-3). Retrieved on February 25, 2003 from http://www.ed.gov/offices/OESE/SIP/TitleIIguid ance2002.doc

Kauffman, J. M. (1994). Places of change: Special education's power and identity in an era of educational reform. Journal of Learning Disabilities, 27(10), 610-618.

Kauffman, J. M. (1996). Research to practice issues. Behavioral Disorders, 22(1), 55-60.

Kauffman, J.M. (1999). Commentary: Today's special education and its message for tomorrow. Journal of Special Education, 32(4), 244-254.

Kennedy, M. M. (1997). The connection between research and practice. Educational Researcher, 26 (7), 4-12.

Kode, K. (2002). Elizabeth Farrell and the history of special education. Arlington, VA: Council for Exceptional Children.

Kozleski, E., Mainzer, R., Deshler, D., Coleman, M., \& RodriguezWalling, M. (2000). Bright Futures for Exceptional Learners: An agenda to achieve quality conditions for teaching and learning. Arlington, VA: Council for Exceptional Children.

Mandlawitz, M. (2003). A tale of three cities: Urban perspectives on special education. Washington, DC: Center on Education Policy.

McLeskey, J., Smith, D., Tyler, N., \& Saunders, S. (2002). The supply and demand of special education teachers: The nature of the chronic shortage of special education teachers. Retrieved February 15, 2003 from http://www.coe.ufl.edu/copsse/PapersFiles/supplydemand.pdf

Miller, D., Brownell, M., \& Smith, S. (1999). Factors that predict teachers staying in, leaving, or transferring from the special education classroom. Exceptional Children, 65, 210-218.

National Center for Educational Statistics, (1992). National adult literacy survey. In The Condition of Education 1995 (pp160). Washington, DC: Author.

National Commission on Teaching and America's Future. (1996). What matters most: Teaching for America's future. New York: Author.

No Child Left Behind Act of 2001 (2002). Retrieved on February 24, 2003 from http://www.ed.gov/legislation/ESEA02/107-110.pdf

Odden, A. (1990). Class size and student achievement: Research-based policy alternatives, Educational Evaluation and Policy Analysis, 12, 213-227.

Olson, L., "Keeping Tabs on Quality," Quality Counts, a supplement to Education Week (January 22, 1997).

Presidential Commission on Excelience in Special Education (2002). A New Era: Revitalizing Special Education for Children and Their Families. Washington, DC: Author.
Robinson, V. M. J. (1998). Methodology and the research-practice gap. Educational Researcher, 27(1), 17-26.

Rosenberg, M. S., \& Sindelar, P. T. (2000). The proliferation of alternative routes to certification in special education: A critical review of the literature. Arlington, VA: Council for Exceptional Children National Clearinghouse for Professions in Special Education.

Russ, S., Chiang, B., Rylance, B., \& Bongers, J. (2001). Caseload in special education: An integration of the research findings. Exceptional Children, 67, 161-172.

Schumaker, J. B., \& Clark, F. L. (1990). Achieving implementation of strategy instruction through effective inservice education. Teacher Education and Special Education, 13(2), 105-116.

Singh, S., \& Billingsley, B. (1996). Intent to stay in teaching: Teachers of students with emotional disturbance versus other special educators. Remedial and Special Education, I 17, 37-47.

Slavin, R. (1986). Best-evidence synthesis: An alternative to meta-analysis and traditional reviews. Educational Researcher, 15, 5-11.

Study of Personnel Needs in Special Education (2001a). Retrieved on February 25, 2003 from http://www.spense.org/scripts/tables/htdocs/ Table 3 17.htm.

Study of Personnel Needs in Special Education (2001b). Retrieved on February 25, 2003 from hours per week http://www.spense.org/scripts/ tables/htdocs/Table1 79.htm.

Swanson, H. L. (1999). Instructional components that predict treatment outcomes for students with learning disabilities: Support for a combined strategy and direct instruction model. Learning Disabilities Research and Practice, 14(2), 129-140.

Tschantz, J., \& Markowitz, J. (2002). Policy forum: Special education paperwork. Alexandria, VA: National Association of State Directors of Special Education.

United States Department of Education. (2001) Twenty-third Annual Report to Congress on the Implementation of the Individuals with Disabilities Education Act. Washington, DC: Author.

Vaughn, S. L., Gersten, R., \& Chard, D. (2000). The underlying message in LD intervention research: Findings from research syntheses. Exceptional Children, 67, 99-114.

Wang, M. C., Haertel, G. D., and Walberg, H. J. (1993, Fall). Toward a knowledge base for school learning. Review of Educational Research, 63(3), 249-294.

Wested (1999, January). Class size reduction: Great hopes Great challenges. Retrieved on February 25, 2003 from http://www.wested.org/ $\mathrm{cs} / \mathrm{pol} / \mathrm{view} / \mathrm{rs} / 182$

Wexler, E., Izu, J., Carlos, L., Fuller, B., Haywood, G. \& Krist, M. (2001). California's class size reduction: Implications for quality practice and implementation. Retrieved August 23, 2001, from www.wested. org/policy/pubs/full-text/class-size/main.html 